\title{
POLA PEMBINAAN ANAK JALANAN DI YAYASAN PEDULI ANAK LOMBOK
}

\author{
Furqan \\ Universitas Islam Negeri (UIN) Mataram \\ Email: itsmefurqon@gmail.com
}

\begin{abstract}
ABSTRAK
Penelitian ini bertujuan untuk mendeskripsikan pembinaan anak jalanan, bagaimana pelaksanaannya, kegiatan pembinaan serta kendala selama pembinaan anak jalanan melalui Yayasan Peduli Anak Lombok. Metode penelitian yang digunakan adalah metode deskriptif dengan pendekatan kualitatif dengan tujuan peneliti dapat mengetahui lebih jauh tentang peranan Yayasan Peduli Anak. Hasil penelitian menunjukkan bahwa pembinaan anak jalanan di Yayasan Peduli Anak difokuskan pada pembinaan pendidikan, kerohanian dan sosial. Pembinaan kerohanian mengarahkan anak untuk membentuk perilaku yang sesuai dengan norma-norma agama. Pembinaan disiplin adalah mendisiplinkan anak sejak dini bertujuan agar anak memiliki jiwa yang disiplin diri dan disiplin waktu. Pembinaan hubungan sosial bertujuan agar anak dapat memiliki hubungan yang baik antar sesama di lingkungan sosial. Pembinaan kebersihan untuk anak agar anak binaan mengetahui pentingnya hidup bersih dan sehat.
\end{abstract}

Kata Kunci: Pembinaan, Anak Jalanan, Yayasan Peduli Anak, Kualitatif

\section{ABSTRACT}

This study aims to describe the development of street children, how they are implemented, coaching activities and obstacles during the development of street children through the Lombok Child Care Foundation. The research method used is descriptive method with a qualitative approach with the aim of researchers to find out more about the role of the Child Care Foundation. The results of the study show that fostering street children at the Children's Care Foundation is focused on educational, spiritual and social development. Spiritual development directs children to form behaviors that are in accordance with religious norms. Discipline guidance is disciplining children from an early age so that children have a spirit of self-discipline and time discipline. Fostering social relations aims to enable children to have good relationships between people in the social environment. Fostering cleanliness for children so that the fostered children know the importance of a clean and healthy life.

Keywords: Coaching, Street Children, Child Care Foundation, Qualitative 


\section{A. Latar Belakang}

Anak jalanan didefinisikan oleh UNICEF sebagai those who have abandoned their home, school, and immediate communities before they are sixteen yeas of age have drifted into a nomadic street life (anak-anak berumur di bawah 16 tahun yang sudah melepaskan diri dari keluarga, sekolah dan lingkungan masyarakat terdekat, larut dalam kehidupan yang berpindah-pindah). Anak jalanan merupakan anak yang sebagian besar menghabiskan waktunya untuk mencari nafkah atau berkeliaran di jalanan atau tempat-tempat umum lainnya. ${ }^{1}$ Hidup menjadi anak jalanan bukanlah pilihan yang menyenangkan, melainkan keterpak saan yang harus mereka terima karena adanya sebab tertentu. Secara psikologis mereka adalah anak-anak yang pada taraf tertentu belum mempunyai bentukan mental emosional yang kokoh, sementara pada saat yang sama mereka harus bergelut dengan dunia jalanan yang keras dan cenderung berpengaruh bagi perkem bangan dan pembentukan kepribadiannya. Aspek psikologis ini berdampak kuat pada aspek sosial.

Penampilan anak jalanan yang kumuh, melahirkan pencitraan negatif oleh sebagian besar masyarakat terhadap anak jalanan yang diidentikan dengan pembuat onar, anak-anak kumuh, suka mencuri, dan sampah masyarakat yang harus diasingkan. ${ }^{2}$ Menurut Suhartini, karakter anak jalanan dapat dilihat

${ }^{1}$ Departemen Sosial RI. Petunjuk Teknis Pelayanan Sosial Anak Jalanan (Jakarta: Departemen Sosial Republik Indonesia, 2005) hlm, 4

${ }^{2}$ Arief Armai, Upaya Pemberdayaan Anak Jalanan, http://anjal.blogdrive.com/archive/11.html diakses pada tanggal 17 Juli 2014.

${ }^{3}$ Tina Suhartini, Skripsi: Strategi Bertahan Hidup Anak Jalanan, Program Studi Komunikasi dan berdasarkan usia, jenis kelamin, tingkat pendidikan, jenis pekerjaan, dan alasan anak turun ke jalan. Usia anak jalanan berusia 13 sampai 18 tahun. Sebagian besar anak jalanan adalah laki-laki dengan jenis pekerjaan sebagai pengamen. Alasan anak turun ke jalan sangat bervariasi, sebagian dari mereka turun ke jalan karena kesulitan ekonomi dan sebagian lagi untuk tambahan uang saku dan rekreasi. ${ }^{3}$ Sebagian besar anak jalanan hanya lulusan Sekolah Dasar (SD) dan Sekolah Menengah Pertama (SMP), diantara SD dan SMP tersebut ada yang tidak tamat sekolah.

Pada kategori pekerjaan, mayoritas anak jalanan adalah pengamen. Pembinaan ialah merupakan usaha yang dilakukan dengan sadar, berencana, terarah, teratur untuk meningkatkan pengetahuan dan keterampilan seseorang dengan tindakan bimbingan, pengarahan, pengawasan untuk mencapai tujuan yang diharapkan. ${ }^{4}$ Dalam mengatasi masalah yang dihadapi anak-anak tersebut, merupakan tugas sebagaimana yang dikembangkan oleh pemerintah tentang pembinaan dan kesejahteraan anak dalam menjamin pertumbuhan dan perkembangannya dengan wajar baik jasmani, rohani maupun sosialnya. Yayasan Peduli Anak merupakan sebuah tempat bagi anak jalanan untuk berkumpul dan dibina oleh tenaga-tenaga professional yang punya jiwa sosial yang membantu mereka. Yayasan Peduli Anak bertujuan membantu anak

Pengembangan Masyarakat, (Bogor: Fakultas Pertanian, IPB. 2008), hlm. 12

${ }^{4}$ Departemen Pendidikan Nasional, Sistem

Penanganan Bagi Anak Jalanan dan Terlantar. Jakarta: Makalah Seminar "Pengembangan Model Penanganan Anak Jalanan Melalui Fungsionalisasi Rumah Singgah di Indonesia”, 20-22 Agustus 2002. ICMI. 
jalanan dalam mengatasi masalahmasalahnya dan menemukan alternatif untuk pemenuhan kebutuhan hidupnya. Dengan demikian Yayasan Peduli Anak bukan merupakan lembaga pelayanan sosial yang membantu menyelesaikan masalah, namun merupakan lembaga pelayanan sosial yang memberikan proses informal dengan suasana resosialisasi bagi anak jalanan terhadap sistem nilai dan norma yang berlaku di masyarakat. ${ }^{5}$ Pada umumnya, keluarga ingin kuat agar anaknya tumbuh dan berkembang menjadi orang yang menjunjung tinggi moral; bisa membedakan mana yang benar dan yang salah, baik dan buruk, pantas dan tidak pantas, sesuai dan tidak sesuai dengan nilai agama dan sosial. ${ }^{6}$

Dari pemikiran tersebut, muncul konsep Yayasan Peduli Anak yang dipilih pemilik Yayasan sebagai wahana yang dipersiapkan untuk menjadi tempat bagi anak jalanan berkumpul dan dibina oleh tenaga profesional yang membantu mereka, dengan mengacu pada konsep yang telah dikembangkan pada Progam Bantuan dan Perlindungan Sosial untuk Anak Jalanan. Fungsi dan tujuan Yayasan Peduli Anak diharapkan dapat membantu anak jalanan mengatasi masalah-masalahnya, dan menemukan alternatif untuk pemenuhan kebutuhan hidupnya. Membentuk kembali sikap dan perilaku anak yang sesuai dengan nilai dan norma yang berlaku di masyarakat, mengupayakan anak kembali ke rumah, panti dan lembaga pengganti lainnya jika

${ }^{5}$ Departemen Sosial RI, Petunjuk Teknis Pelayanan Sosial Anak Jalanan, (Jakarta: Departemen Sosial Republik Indonesia, 2005), hlm. 12

${ }^{6}$ Muhammad Al-Mighwar, Psikologi Remaja, (Bandung: CV.Pustaka Setia, 2011), hlm. 213

${ }^{7}$ Opcit, Departemen Sosial RI, hlm, 12-13 diperlukan, serta memberikan berbagai alternatif pelayanan untuk pemenuhan kebutuhan anak dan menyiapkan masa depannya, sehingga menjadi warga masyarakat yang produktif. ${ }^{7}$

\section{B. Metode}

Penelitian ini menggunakan pendekatan kualitatif dengan metode deskriptif. Penelitian kualitatif dilakukan karena peneliti ingin mengeksplor fenomenafenomena yang tidak dapat dikuantifikasi kan yang bersifat deskriptif seperti proses suatu langkah kerja, formula suatu resep, pengertian-pengertian tentang suatu konsep yang beragam, karakteristik suatu barang dan jasa, gambar-gambar, gaya-gaya, tata cara suatu budaya, model fisik suatu artefak dan lain sebagainya. ${ }^{8}$ Karena data yang diperoleh berupa kata-kata atau tindakan, maka jenis penelitian yang peneliti gunakan adalah jenis penelitian deskriptif, yakni jenis penelitian yang hanya menggambarkan, meringkas berbagai kondisi, situasi atau berbagai variabel. Menurut Moleong, penelitian deskriptif merupakan penelitian yang datanya dikumpulkan berupa kata-kata, gambar, dan bukan angka-angka. ${ }^{9}$ Yayasan Peduli Anak merupakan tempat praktek penulis sebagai pekerja sosial dan pengasuhnya anak-anak jalanan, sehingga penulis merasa perlu diangkat untuk jadi bahasan dalam dunia akademik.

\section{Hasil Penelitian}

Lembaga yang menjadi pembahasan dalam artikel ini adalah Yayasan Peduli

${ }^{8}$ Satori dan Komariah, Metodologi Penelitian Kualitatif, (Bandung: CV. Alfa Beta Cetakan IV, 2012), hlm. 23

${ }^{9}$ Lexy J Moleong, Metodelogi Penelitian Kualitatif, (Bandung: PT. Rosda Karya, 2002), hlm. 3 
Anak yang terletak di Desa Langko Kecamatan Lingsar Kabupaten Lombok Barat. Dalam penelitian ini, yang menjadi objek penelitian adalah proses pembinaan di Yayasan Peduli Anak dan anak jalanan yang terdapat di Yayasan Peduli Anak. Adapun yang menjadi masalah umum dalam penelitian ini adalah "Bagaimana kah pembinaan anak jalanan di Yayasan Peduli Anak Lombok?". Sedangkan masalah khususnya adalah bagaimana pelaksanaan pembinaan, apa saja kegiatan yang dilakukan dalam pembinaan serta kendala apa saja yang dihadapi selama pembinaan di Yayasan Peduli Anak yang terletak di Desa Langko Kecamatan Lingsar Kabupaten Lombok Barat. Berikutnya, untuk menjawab sub-sub masalah yang dikemukakan di atas, peneliti melakukan wawancara dan observasi dengan informan. Adapun yang menjadi informan dalam penelitian ini adalah pimpinan dan atau pengasuh anak dan anak jalanan yang dibina di Yayasan Peduli Anak. Pimpinan Yayasan Peduli Anak adalah Ibu Nurdiana. Data anak jalanan yang dibina di Yayasan Peduli Anak adalah sebanyak 84 orang. Program kegiatan yang ada di Yayasan Peduli Anak meliputi pembinaan pendidikan, sosial dan kerohanian. Pendekatan yang dilakukan pada anak binaan lebih kepada masalah sosial anak serta pemberian binaan kerohanian yang lebih.

Pembinaan yang dilakukan di Yayasan Peduli Anak tidak mengacu pada standar layanan Dinas Sosial, karena lebih dipertimbangkan kepada masalah yang ada di lingkungan sekitar anak jalanan. Kegiatan yang dilakukan meliputi pembinaan rohani yang bertujuan untuk meningkatkan anak binaan agar selalu beriman dan bertakwa kepada yang Maha Kuasa, disiplin diri dan disiplin waktu yang dibina sejak anak masih dini, membina anak untuk memiliki hubungan sosial yang baik antar sesama, dan mengajarkan anak pentingnya menjaga hidup bersih dan sehat.

Sejauh ini pembinaan anak jalanan di Yayasan Peduli Anak berjalan dengan baik, anak binaan mulai terbentuk perila kunya, mereka disiplin dan hubungan sosial antar teman-temannya terbina dengan baik. Masalah pelajaran di sekolah yang kurang dimengerti, anak binaan sering mendiskusikan kepada para pengasuh hal apa saja yang mereka tidak pahami dalam belajar. Semua materi pelajaran di sekolah ditekankan pada pembinaan di Yayasan seperti Bahasa Inggris, Matematika, IPA dan mata pelajaran lainnya. Pelajaran bahasa Inggris mereka ditekankan untuk mempraktekkan langsung karena di Yayasan begitu banyak volunteers dari luar negeri ikut membantu dalam hal pendidikan dan pelatihan sehingga mempermudah anakanak berlatih komunikasi dalam bahasa inggris. Selain pelajaran-pelajaran tersebut tidak menutup kemungkinan anak binaan yang mengalami kesulitan di bidang studi yang lainnya dapat bertanya sesuai dengan bidang studi tersebut pada pengasuh. Kendala yang sering dihadapi dalam pelayanan di Yayasan Peduli Anak ini adalah kurangnya tenaga-tenaga pro fessional seperti pengasuh dan konselor yang relevan dengan dunia pekerjaan sosial.

Dari hasil studi wawancara pada anak jalanan diketahui semua anak jalanan yang dibina di Yayasan Peduli Anak yang ratarata merupakan anak-anak berdomisili atau 
bertempat tinggal di pulau Lombok dan Sumbawa Semua anak jalanan yang dibina berasal dari keluarga menengah ke bawah dan mereka ada yang bersekolah di sekolah dasar negeri maupun swasta yang ada di Lombok dan Sumbawa, yang kebanyakan dari mereka adalah siswa putus sekolah. Alasan utama mereka berada di jalanan dikarenakan ekonomi yang kurang baik sehingga mengharuskan mereka mencukupi kehidupan dengan cara mencari uang di jalanan. Selama mereka bergabung dan dibina di Yayasan Peduli Anak, mereka menemukan suatu keluarga kecil, mereka diberikan pendidikan tidak hanya dalam hal akademik melainkan dalam hal sosial maupun kerohanian. Mereka juga dapat menyalurkan bakat serta keterampilan yang dapat menjadi bekal untuk mereka ke depan. Selama berada di Yayasan Peduli Anak, mereka merasa senang dan merasa diperhatikan, mereka tidak lagi merasa sendiri tapi mereka mempunyai keluarga kecil. Pembinaan anak di Yayasan Peduli Anak merupakan wadah tempat mereka berkumpul dan saling berbagi kepada sesama. Hasil studi observasi menggam barkan kegiatan pembinaan dilakukan beragam tidak hanya pembinaan dalam hal pendidikan saja melainkan kegiatan lainnya, seperti kegiatan sosial, keterampilan serta kegiatan rohani. Waktu pembinaan dilakukan setiap hari, karena pengasuh sebagai Pembina selalu berada di Yayasan 24 jam. Berikut akan dilampirkan beberapa tabel hasil observasi.

\section{Tabel 1. Hasil Observasi Pembinaan Anak Jalanan di Yayasan Peduli Anak Waktu Aspek yang Diamati Deskripsi dan Keterangan}

\begin{tabular}{|l|l|l|l|}
\hline Waktu & Aspek yang diamati & Deskripsi & Keterangan \\
\hline $\begin{array}{l}\text { Senin, 07 Mei } \\
\text { Pe18 }\end{array}$ & $\begin{array}{l}\text { Program/Kegiatan } \\
\text { Pembinaan }\end{array}$ & $\begin{array}{l}\text { Difokuskan pada } \\
\text { pembinaan } \\
\text { pendidikan, sosial } \\
\text { dan kerohanian. }\end{array}$ & $\begin{array}{l}\text { Dengan dibimbing } \\
\text { oleh Ibu Indri } \\
\text { Widiasari, anak } \\
\text { binaan melakukan } \\
\text { kegiatan belajar } \\
\text { mandiri. }\end{array}$ \\
& $\begin{array}{l}\text { Model pembinaan } \\
\text { pendidikan }\end{array}$ & $\begin{array}{l}\text { Mendorong anak } \\
\text { agar dapat aktif di } \\
\text { sekolah serta } \\
\text { mengulangi } \\
\text { pelajaran agar anak } \\
\text { dapat lebih } \\
\text { memahami pelajaran } \\
\text { di sekolah }\end{array}$ & \\
& & Mendisiplinkan anak & \\
& & $\begin{array}{l}\text { Pejak dini, baik } \\
\text { disiplin diri maupun } \\
\text { disiplin waktu }\end{array}$ & \\
& & \\
& &
\end{tabular}




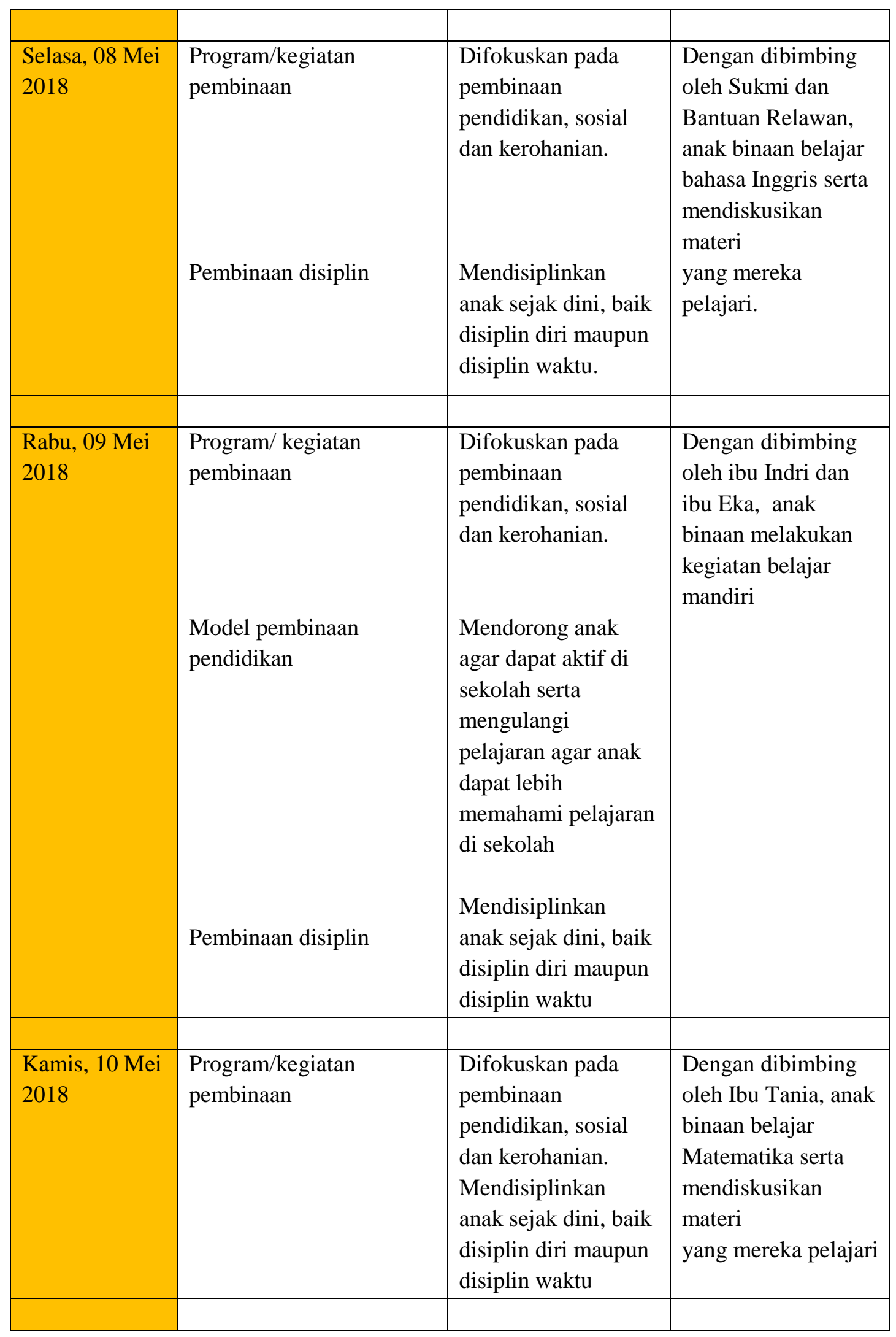




\begin{tabular}{|c|c|c|c|}
\hline $\begin{array}{l}\text { Jumat, } 11 \text { mei } \\
2018\end{array}$ & $\begin{array}{l}\text { Pembinaan kebersihan } \\
\text { Pembinaan hubungan } \\
\text { sosial }\end{array}$ & $\begin{array}{l}\text { Melakukan } \\
\text { pembinaan pada } \\
\text { anak jalanan dalam } \\
\text { masalah-masalah } \\
\text { sosial serta } \\
\text { hubungannya } \\
\text { terhadap } \\
\text { masyarakat. } \\
\text { Mengajarkan anak } \\
\text { pentingnya menjaga } \\
\text { hidup bersih dan } \\
\text { sehat } \\
\text { Mengajarkan anak } \\
\text { untuk memiliki } \\
\text { hubungan yang baik } \\
\text { antar sesama } \\
\text { dimulai dari } \\
\text { hubungan sosial } \\
\text { antar anak-anak } \\
\text { binaan }\end{array}$ & $\begin{array}{l}\text { Pembina Yayasan } \\
\text { melakukan } \\
\text { kegiatan sosial ke } \\
\text { anak } \\
\text { jalanan yang belum } \\
\text { tergabung dalam } \\
\text { Yayasan Peduli } \\
\text { Anak } \\
\text { Pendekatan yang } \\
\text { dilakukan dengan } \\
\text { membagikan alat } \\
\text { alat keperluan } \\
\text { mandi, } \\
\text { serta mengajak anak } \\
\text { jalanan untuk mandi } \\
\text { di } \\
\text { sungai }\end{array}$ \\
\hline $\begin{array}{l}\text { Sabtu, 12 Mei } \\
2018\end{array}$ & $\begin{array}{l}\text { Program/kegiatan } \\
\text { pembinaan } \\
\text { Pembinaan kerohanian } \\
\text { Pembinaan disiplin }\end{array}$ & $\begin{array}{l}\text { Difokuskan pada } \\
\text { pembinaan } \\
\text { pendidikan, sosial } \\
\text { dan kerohanian. } \\
\text { Mengingatkan anak } \\
\text { agar selalu beriman } \\
\text { dan bertakwa. } \\
\text { Mendisiplinkan } \\
\text { anak sejak dini, baik } \\
\text { disiplin diri maupun } \\
\text { disiplin waktu }\end{array}$ & $\begin{array}{l}\text { Kegiatan dibimbing } \\
\text { oleh Pak Dani. } \\
\text { Anak-anak } \\
\text { dibimbing } \\
\text { dalam hal } \\
\text { kerohanian, } \\
\text { diajarkan moral- } \\
\text { moral dalam } \\
\text { keagamaan juga } \\
\text { disiplin diri serta } \\
\text { sharing dalam } \\
\text { masalah-masalah } \\
\text { yang dihadapi } \\
\text { anak-anak binaan. }\end{array}$ \\
\hline $\begin{array}{l}\text { Minggu, } 13 \\
\text { Mei } 2014\end{array}$ & Pembinaan Sosial & $\begin{array}{l}\text { Mengajak anak } \\
\text { bersosialisasi dan } \\
\text { berekreasi }\end{array}$ & $\begin{array}{l}\text { Kegiatan di } \\
\text { Bimbing oleh } \\
\text { Semua Pembina, } \\
\text { anak-anak } \\
\text { melakukan } \\
\text { refreshing agar }\end{array}$ \\
\hline
\end{tabular}




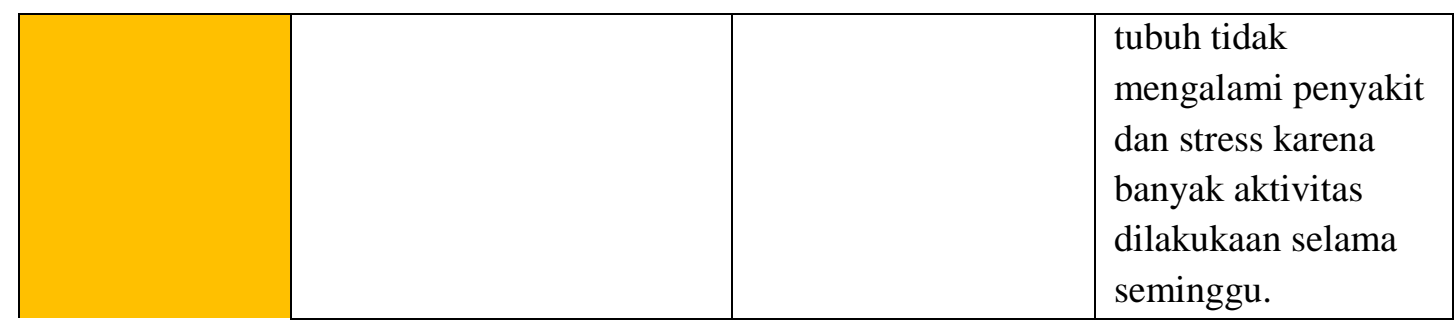

\section{Pembahasan}

Di Yayasan Peduli Anak agar pembinaan berjalan tertib sekaligus untuk melatih kedisiplinan anak, pihak yayasan membuat jadwal kegiatan yang sifatnya tetap dan harus diikuti oleh semua anak tanpa terkecuali, yang disertai sanksi yang tegas apabila ada setiap pelanggaran yang terjadi. Sanksi itu biasanya berupa hukuman yaitu penugasan untuk membersihkan lingkungan Yayasan. Hal ini sesuai dengan teori perkembangan moral menurut Jean Piaget, yang dikutip oleh Burhanuddin Salam, bahwa pada tahap heteronomy atau realisme moral, anak-anak merasa wajib mengikuti aturan-aturan, karena aturan itu adalah Undang-Undang dan tidak dapat diubah. Anak cenderung memandang peraturanperaturan itu secara total adalah benar atau salah, dan mengira bahwa setiap orang memandang aturan-aturan itu dengan cara yang sama. ${ }^{10}$ Anak memutuskan kesalahan atau kebenaran suatu tindakan atas dasar besar kecilnya akibat-akibat yang ditim bulkannya, dan apakah tindakan-tindakan itu akan dihukum atau tidak.

Berdasarkan pengamatan, anak binaan telah megikuti pembinaan secara aktif dan mematuhi jadwal kegiatan yang telah ditetapkan. Disamping itu para pengasuh sendiri dalam memberikan pembinaan juga penuh kedisiplinan tetapi disertai rasa kekeluargaan sehingga anak merasa senang tidak merasa takut, namun tetap menghormati para pengasuh, bahkan mereka menganggap para pengasuh sebagai figur yang baik. Para pengasuh dan anak binaan saling bekerjasama untuk mencapai keberhasilan tersebut, karena keberhasilan pembinaan tidak hanya tergantung para pengasuhnya akan tetapi anak didiknya juga sangat menentukan keberhasilan pembinaan. Pribadi yang terdidik adalah seorang yang belajar di sekolah atau di manapun juga untuk hidup dalam satu cara yang merefleksikan kesan dan praktek untuk dikembangkan norma-norma dan cita-cita sosial. Pribadi yang terdidik secara moral adalah seorang yang telah belajar untuk bertindak dalam cara-cara tertentu dan menjadi sadar dan bahagia dengan tindakantindakan dan nilai-nilainya. Yayasan Peduli Anak menetapkan norma dan atau peraturan yang harus ditaati untuk melatih disiplin anak binaannya. Norma itu misalnya mentaati jadwal kegiatan, jika keluar atau ijin pulang harus seijin pengasuh atau petugas, menghormati yang tua dan menyayangi yang lebih muda serta selalu disiplin waktu.

\footnotetext{
${ }^{10}$ Burhanuddin Salam, Etika Individual Pola Dasar Filsafat Moral, (Jakarta: Rineka Cipta, 2000), hlm. 67
} 
Dalam pembinaan, anak jalanan juga mendapatkan pelajaran moral dengan meneladani sikap pengasuh yang ber-disiplin dan sangat menyayangi anak binaannya. Hal ini tercermin dari kepedulian pengasuh terhadap masalah-masalah yang dihadapi anak binaannya, baik itu masalah pribadi maupun masalah kelompok. Hal ini sesuai dengan pendapat Sugeng Hariyadi, bahwa upaya pengemba ngan nilai, moral dan sikap dapat dilakukan dengan modeling yaitu upaya yang memerlukan contoh nyata dari model dari pengasuh. Anak jalanan tidak hanya butuh sekedar nasihat tetapi mereka memerlukan model untuk ditiru dan identifikasi sebagai dasar pembentukan nilai moral dan sikapnya. ${ }^{11}$ Kegiatan pembinaan anak jalanan juga diajarkan masalah kebersihan yang bertujuan untuk agar anak mengetahui betapa pentingnya hidup bersih dan sehat. Pembinaan kebersihan yang diajarkan misalnya, bagaimana cara menggosok gigi yang benar, menu makan seimbang yang baik, bagaimana menjaga kebersihan kuku tangan dan kaki, serta anak juga diajarkan untuk menjaga kebersihan lingkungan sekitar. Pembinaan yang dilakukan kepada anak jalanan terjadwal setiap hari Senin, Rabu dan Jum'at.

\section{E. Kesimpulan}

Berdasarkan penelitian tentang pembinaan anak jalanan di Yayasan Peduli anak Lombok Desa Langko Kecamatan Lingsar Kabupaten Lombok Barat NTB, dapat disimpulkan sebagai berikut: 1) Pelaksanaan Pembinaan anak jalanan bertujuan untuk menanamkan nilai-nilai yang mengarahkan anak dengan membekali mental spiritual dan keterampilan kepada anak binaan, sehingga dapat kembali melakukan fungsi sosialnya di masyarakat, berguna dan produktif. Para pengasuh memberikan contoh menjadi teladan yang disiplin juga dalam memberikan pembinaan penuh kedisiplinan, supaya anak dalam mengikuti pembinaan juga disiplin dan mematuhi semua peraturan yang ada. 2) Kegiatan yang dilakukan dalam pembinaan anak jalanan di Yayasan Peduli Anak, agar berjalan tertib serta sekaligus untuk melatih kedisip linan anak, pihak Yayasan membuat jadwal kegiatan yang sifatnya tetap dan harus diikuti oleh semua anak tanpa terkecuali, yang disertai sanksi yang tegas apabila ada setiap pelanggaran yang terjadi. Sanksi itu biasanya berupa huku man yaitu penugasan untuk membersihkan lingkungan rumah singgah. 3) Kendala yang sering dihadapi dalam pembinaan anak jalanan di Yayasan Peduli Anak adalah seperti kendala yang sering dihadapi dalam pelayanan di Yayasan Peduli Anak ini adalah kurangnya tenaga-tenaga professional seperti konselor yang dibutuhkan dalam membina anak jalanan untuk melakukan pembinaan, sarana serta prasarana cukup mendukung hanya saja dibutuhkan juga biaya pemeliharaan.

\section{F. Saran}

Berdasarkan hasil penelitian dan kesimpulan di atas, maka dapat disampaikan saran sebagai berikut: 1) Bagi Yayasan Peduli Anak, pembinaan di Yayasan Peduli Anak sudah baik, sehingga diharapkan dapat mempertahankannya dan berusaha untuk meningkatkannya agar menjadi lebih baik lagi. Pengasuh harus lebih bersabar dalam

${ }^{11}$ Sugeng Haryadi, Psikologi Perkembangan.

(Semarang: UNNES Press, 2003), hlm. 94-96 
membina anak di Yayasan Peduli Anak khususnya dalam membina anak jalanan yang nakal. 2) Bagi anak jalanan, hendaknya mengikuti pembinaan dengan sungguhsungguh, mematuhi semua peraturan yang berlaku dan berusaha menambah pengetahuan mereka, misalnya dengan mengikuti secara aktif kegiatan pembinaan di Yayasan Peduli Anak. 3) Kendala yang sering dihadapi dalam pelayanan di Yayasan ini adalah adalah kurangnya tenaga-tenaga professional seperti konselor yang dibutuhkan dalam membina anak jalanan.

\section{DAFTAR PUSTAKA}

Al-Mighwar, Muhammad. 2011. Psikologi

Remaja. Cetakan II. Bandung: CV. Pustaka Setia.

Arief, Armai. 2002. Upaya Pemberdayaan

Anak Jalanan.

http://anjal.blogdrive.com/archive/11.ht

ml. Diakses pada tanggal 17 Juli 2014.

Departemen Pendidikan Nasional.2002. Sistem

Penanganan Bagi Anak Jalanan dan

Terlantar. Jakarta: Makalah Seminar "Pengembangan Model Penanganan Anak Jalanan Melalui Fungsionalisasi Rumah Singgah di Indonesia”, 20-22 Agustus. ICMI.

Departemen Sosial RI.2005. Petunjuk Teknis Pelayanan Sosial Anak Jalanan. Jakarta: Departemen Sosial Republik Indonesia.

Hariyadi, Sugeng. 2003. Psikologi Perkembangan. Semarang: UNNES Press.

Moleong, Lexy. 2002. Metodelogi Penelitian Kualitatif. Bandung: PT. Rosda Karya.

Salam, Burhanuddin. 2000. Etika Individual Pola Dasar Filsafat Moral. Jakarta: Rineka Cipta.
Satori dan Komariah. 2012. Metodologi Penelitian Kualitatif. Cetakan IV. Bandung: CV. Alfa Beta.

Suhartini, Tina. 2008. Strategi Bertahan Hidup Anak Jalanan. Bogor: Skripsi. Program Studi Komunikasi dan Pengembangan Masyarakat, Fakultas Pertanian,IPB. 